\title{
BUSINESS STRATEGIES: RUMUSAN STRATEGI MENINGKATKAN PEREKONOMIAN SEKTOR UMKM DI TENGAH PANDEMI
}

\author{
Priska Rahmawati', Nur Azis² ${ }^{\text {, Budi Utomo3 }}$ \\ IAIN Salatiga,
}

priskarahmao4@gmail.com ${ }^{1}$; nurazis.as.febi@gmail.com² ; $\underline{\text { budiutomo@iainsalatiga.ac.id3 }}$

\begin{abstract}
ABSTRAK
Pandemi Covid-19 telah melanda Indonesia, hal ini mengakibatkan penurunan tingkat pendapatan dalam perekonomian. UMKM merupakan salah satu sektor yang terkena dampak pandemi ini. Pelaku usaha UMKM mengalami penurunan tingkat pembeli, hal ini terjadi karena adanya kebijakan PPKM (Pemberlakuan Pembatasan Kegiatan Masyarakat). Penelitian ini bertujuan untuk menjawab permasalahan yang dihadapi oleh pelaku usaha UMKM dan memberikan strategi bisnis baru supaya bisa bertahan di tengah pandemi. Metode penelitian dalam penelitian ini menggunakan analisis kualitatif dengan teknik pengumpulan data observasi partisipasi dan menggunakan sumber data sekunder. Hasil penelitian ini berupa rumusan strategi bisnis baru yaitu, melakukan penjualan $E$ Commerce, melakukan pemasaran dengan digital marketing, memperbaiki kualitas produk dan layanan, serta menjalin hubungan baik dengan konsumen (Customer Relationship Marketing). Dengan adanya penelitian ini akan memberikan kontribusi kepada pelaku UMKM untuk mempertahankan bisnisnya di masa pandemi, dan jangka panjangnya akan meningkatkan pendapatan nasional melalui sektor UMKM.
\end{abstract}

Kata Kunci : Covid-19, UMKM, Strategi Bisnis

\section{ABSTRACT}

The Covid-19 pandemic has hit Indonesia, this has resulted in a decline inthe levelof income in the economy. MSMEs are one of the sectors affected by this pandemic. Msme business actors experienced a decrease in the level of buyers, this happened because of the PPKM policy (Enforcement of Restrictions on Community Activities). This sutudy aims to answer the problems faced by MSME business actors and provide new business strategies in order to survive in the midst of a pandemic. The research method in this study uses qualitative analiysis with data collection techniques of participation observation and the use of secondary data sources. The results of this study are the formulation of new business strategies,namely, selling E-Commerce, marketing with digital marketing,improving product and service quality, and estabilishinggood relationship with consumers (Customer Relationship Marketing). With this research, it will contribute to MSME actors tomaintain their business during the pandemic, and in the long term it will increase national income through the MSME sector.

Keywords: Covid-19, MSME, Business Strategies

Diterima: 11 September 2021; Direvisi: 28 September 2021; Diterbitkan: Oktober 2021 


\section{PENDAHULUAN}

Akhir tahun 2019 dunia di gegerkan dengan adanya pandemi Covid-19. Covid19 telah menyebar ke seluruh penjuru dunia, termasuk Indonesia. Covid-19 memberikan dampak yang signifikan terhadap tingkat perekonomian. Hal ini dapat berdampak pada sektor pariwisata, perdagangan, dan industri pengolahan yaitu UMKM (Usaha Kecil Mikro Menengah) yang ikut mengalami penurunan pendapatan. Tercatat kasus Covid-19 pada 28 Mei 2021 terdapat 1.803.361 kasus, 1.654.557 meninggal, dan 50.100 sembuh (Covid19.go.id).

Perlu diketahui bahwa sebagian besar penduduk Indonesia didominasi oleh pekerja informal dan pengusaha UMKM (Usaha Mikro, Kecil, dan Menengah). Data dari Kementrian Koperasi dan Usaha Kecil Menengah (KemenkopUKM) menunjukkan bahwa pada tahun 2019 terdapat 65.465.497 UMKM yang ada di Indonesia (atau sekitar 99,99 persen dari total unit usaha) dan memperkerjakan 119.562.843 tenaga kerja (atau sekitar 96,92 persen dari total tenaga kerja di sektor ekonomi) (kemenkopukm.go.id). Akibat adanya pandemi Covid-19 terdapat beberapa pengaruh besar yang dirasakan pada sektor UMKM, diantaranya penurunan konsumsi dan daya beli masyarakat, penurunan kinerja perusahaan, ancaman pada sektor perbankan dan keuangan, serta penurunan eksistensi UMKM yang akhirnya berdampak pada pemutusan hubungan kerja (PHK) dan ancaman macetnya pembayaran kredit.

Jika pandemi ini berlangsung lama, kemungkinan besar penurunan ekonomi juga akan bertambah. Menurut Kurniawansyah et al (2020) dalam Yamali
\& Putri, (2020) Dampak ini secara otomatis akan mempengaruhi penurunan daya beli masyarakat yang mana perputaran uang akan menjadi sangat minim di tengah masyarakat serta pada saat yang sama juga produksi barang akan terbatas dan menyebabkan defisit perdagangan. Menurut Nasir \& Khoirudin (2020) UMKM adalah sebagai penyedia lapangan kerja bagi masyarakat Indonesia. Namun, UMKM dirasa masih bisa dimaksimalkan untuk menopang lapangan pekerjaan dan perekonomian Indonesia. UMKM di Indonesia dapat dimaksimalkan dengan mengatasi masalah yang ada di UMKM tersebut mulai dari modal usaha, manajemen usaha, dan SDM. Pelaku bisnis UMKM Indonesia harus terus memperbaiki diri dengan menciptakan daya saing yang global maupun internasional agar tetap mempertahankan ekistensinya di dunia bisnis (Maulina \& Sari, 2017).

Selama pandemi berlangsung pemerintah telah mengeluarkan kebijakan-kebijakan yang diharapkan bisa menekan penularan virus Covid-19 yaitu, Social Distancing, Physical Distancing, Lockdown, PSBB (Pembatasan Sosial Berskala Besar) hingga penyuntikan vaksinasi, tetapi sampai saat ini belum menujukkan keberhasilan. Dengan hal ini, para pelaku usaha dapat memanfaatkan $E$ Commerce sebagai media penjualannya. E-Commerce dapat di definisikan sebagai metodologi bisnis modern yang membahas kebutuhan organisasi, pedagang, dan konsumen untuk memangkas biaya sekaligus meningkatkan kualitas barang dan jasa serta meningkatkan kecepatan penyampaian layanan, dengan menggunakan internet (Goel, 2007). Dalam penelitian HELMALIA \& AFRINAWATI, (2018) bahwa $E$ - 
Commerce berpengaruh positif dan signifikan terhadap pendapatan UMKM.

Selain E-Commerce pelaku usaha dapat menerapkan digital marketing. Diharapkan pelaku usaha dapat memasarkan produknya melalui digital marketing dan memanfaatkan media sosial sebagai sarana pendukungnya. Digital marketing merupakan pencapaian tujuan pemasaran melalui penerapan media digital, data, dan teknologi (Chaffey \& Chadwick, 2019). Dalam penelitian (Hendrawan, Sucahyowati, Cahyandi, Indriyani, \& Rayendra, 2019) menyatakan bahwa digital marketing berpengaruh terhadap kinerja penjualan produk UMKM.

Pandemi Covid-19 ini menyebabkan perubahan perilaku terhadap konsumen. Biasanya dalam hal membeli barang/produk konsumen melakukan pembelian ke toko langsung. Namun, setelah adanya pandemi Covid-19 dengan diberlakukannya beberapa kebijakan oleh pemerintah yaitu berupa Social Distancing, Physical Distancing, Lockdown, dan PSBB menjadikan kebiasaan konsumen dari yang membeli ke toko langsung beralih ke toko online atau E-Commerce. Berdasarkan survei Bank DBS Indonesia mencatat bahwa pelanggan E-Commerce di Indonesia mengalami kenaikan menjadi 66 persen setelah pandemi Covid-19 (Catriana, 2021). Maka dari itu, diperlukan adanya perbaikan kualitas produk dan kualitas pelayanan produk agar dapat menarik konsumen. Menurut Kotler \& Amstrong (2010) kualitas produk adalah kemampuan suatu produk untuk melaksanakan fungsinya, meliputi kehandalan, daya tahan, ketepatan, kemudahan operasi, dan perbaikan produk, serta atribut bernilai lainnya. Sedangkan kualitas pelayanan adalah tingkat keunggulan yang diharapkan dan pengendalian atas tingkat keunggulan tersebut untuk memenuhi keinginan pelanggan (Tjiptono, 2009). Hal ini sesuai dengan penelitian yang dilakukan oleh (Jackson R.S. Weenas, 2013) yang menyatakan bahwa kualitas produk dan kualitas pelayanan berpengaruh positif terhadap keputusan pembelian.

Dampak pandemi Covid-19 ini mengakibatkan turunnya penjualan dan kepercayaan konsumen sehingga berpengaruh terhadap bisnis yang dijalankan. Maka dari itu, pelaku usaha perlu untuk membangun kepercayaan dan hubungan baik dengan konsumen (relationship marketing). Menurut Kotler \& Amstrong (2010) relationship marketing merupakan orientasi bisnis yang terfokus pada menjaga hubungan baik dengan pelanggan yang sudah ada dan membangun hubungan yang erat dan saling menguntungkan antara pelaku usaha dan konsumen hingga menciptakan transaksi ulang hingga terbentuk loyalitas konsumen. Hal ini sejalan dengan penelitian Akbar,(2018) menyatakan bahwa relationship marketing berpengaruh positif terhadap kepuasan pelanggan dan loyalitas pelanggan.

Penelitian ini semoga bisa membantu UMKM dalam menjawab permasalahan-permasalahan yang ada selama pandemi agar tetap menjalankan bisnisnya. Penelitian ini bertujuan untuk merumuskan strategi bisnis untuk UMKM agar dapat bertaha dan tetap eksis di tengah pandemi Covid-19.

\section{KAJIAN TEORETIK}

\section{Pandemi Covid-19}

Pandemi Covid-19 yang melanda dunia merupakan persoalan global yang 
harus segera diatasi oleh pemerintah. Pandemi ini pertama kali muncul di Wuhan, China pada Desember 2019. Perkembangan pandemi ini sangat cepat, tercatat hingga Tercatat kasus Covid-19 pada 28 Mei 2021 terdapat 1.803.361 kasus, 1.654.557 meninggal, dan 50.100 sembuh (Covid19.go.id)

Menurut Widiawati dan Mas'uid dalam Yamali \& Putri, (2020) Pandemic covid 19 ini membuat pemerintah Indonesia telah mengeluarkan regulasi/kebijakan terkait penanganannya. Adapun regulasi/kebijakan yang dimaksud antara lain 4 Keputusan Presiden, 2 Peraturan Presiden, 1 Peraturan Pemerintah, 1 instruksi Presiden da 1 Peratuaran Pemerintah Pengganti Undang-Undang. Peraturan-peraturan yang telah dibuat tersebut merupakan alternative pemecahan masalah yang dapat dilihat dari sisi kesehatan, birokrasi, politik maupun keuangan Negara Indonesia yang diakibatkan dari pandemic covid-19.

Menurut Mas'ud dan Winarti dalam Yamali \& Putri, (2020) eksternalitas Covid-19 ini telah melemahkan peluang mereka dalam menghasilkan pendapatan sehari-harinya, terjadinya PHK besarbesaran pada pekerja yang mencapai 1.943.916 orang yang terdiri dari 114.340 perusahaan. Kejadiaan ini akan mengalami peningkatan angka yang terus meningkat apabila pandemic ini berlangsung lama. Selain itu, dengan adanya himbauan "stay at home" kepada masyarakat akan mengakibatkan penurunan penghasilan masyarakat dari rutinitasnya secara signifikan, aktivitas ekonomi menjadi sangat terbatas, serta pengaruh lain yang mengikutinya.

\section{UMKM}

Berdasarkan undang-undang Nomer 20 tahun 2008, Usaha kecil dan Menengah (UKM) merupakan jenis usaha kecil yang memiliki kekayaan bersih paling banyak Rp 200.000.000 tidak termasuk tanah dan bangunan tempat usaha. dan usaha yang berdiri sendiri. Keberadaan UMKM di Indonesia sangatlah berperan dalam menekan tingkat pengangguran. Pasalnya perkembangan pelaku usaha di indonesia semakin tahun terus mengalami kenaikan (Alfin, 2021)

Pengembangan UMKM harus diletakkan sebagai usaha peningkatan produktivitas sektor publik. Holzer \& Callahan mengemukakan bahwa integrasi manajemen yang berkualitas, pengembangan sumber daya manusia, adaptasi tehnologi, kemitraan strategis dan ukuran kinerja organisasi, akan menghasilkan akan peningkatan produktivitas sector publik apabila disinergikan dengan modal, tenaga kerja dan energi. Mengingat saat ini dunia, termasuk Indonesia, masuk era infomasi berbasis teknologi yang oleh Alvin Toffer didefinisikan sebagai gelombang ketiga manusia Dhyah Ayu Retno Widyastuti \& Sidhi, (2016). Maka dari itu, untuk meningkatkan kualitas dan pengembangan UMKM dapat ditempuh melalui teknologi digital.

\section{Strategi Bisnis (Business Strategies)}

Organisasi bisnis (perusahaan) dapat tumbuh dan berkembangan apabila dalam menjalankan aktivitas usahanya berpegang pada konsep efektivitas dan produktivitas. Tidak dapat dipungkiri berdirinya organisasi bisnis adalah pencapaian keuntungan laba (provit) secara optimal. Langkah untuk memenangkan persaingan adalah dengan menerapkan strategi pemasaran yang tepat sasaran baik dari segi kualitas, harga, 
maupun daya saing atas produk yang dihasilkannya

Maka dari itu para pengusaha terutama pada sektor pelaku usaha (UMKM) harus melakukan trobosoan atau membuat strategi bisnis untuk mengatasi masalah ekonomi karena pandemi Covid19 ini. Strategi bisnis yang tepat untuk memasarkan produk di masa pandemi covid19 ini adalah melalui digital marketing dimana antara penjual dan pembeli tidak bertemu secara langsung pada satu tempat tetapi memiliki jangkauan pemasaran yang sangat luas bahkan sampai mancanegara.

(Soehardi \& Sable, 2019) menguraikan strategis marketing untuk meningkatkan pendapatan usaha mikro, kecil dan menengah adalah sebagai berikut:

1. Kebijakan pemerintah daerah dan pusat dalam mendukung aksesibilitas transportasi udara, laut dan darat seperti pembangunan infrastruktur International Airport and Seaport;

2. Daya tarik daerah tujuan wisata attraktif agar banyak turis domestik dan asing berkunjung ke tempattempat pariwisata sehingga produk, jasa dan pendapatan UMKM semakin meningkat;

3. Jejaring media sosial dalam mempromosikan produk dan jasa UMKM;

4. Pemasaran produk dan jasa UMKM melalui smartphone agar lebih efektif dan efisien;

5. Membentuk gugus tugas UMKM terintegrasi atau Integrated Tourism and MSME (Micro, Small and Medium Enetrprises) Task Force dalam menyatukan perencanaan, pelaksanaan, pengorganisasian dan monitoring and evaluation;
6. Perlu dukungan Integrated software program yang mengikuti perkembangan new information and communication technology begitu pesat dalam mendukung transaksi pembayaran produk dan jasa bisnis UMKM;

7. Peningkatan kualitas dan kuantitas sumber daya manusia pelaku dan pegawai UMKM yang memiliki kompetensi sertifikasi nasional dan internasional

8. Kemudahan pelasayanan Accessability di tempat-tempat Financial technology (Fintech) (Hidayat et al., 2021)

\section{METODE PENELITIAN}

Dalam penelitian ini, peneliti menggunakan metode kualitatif. Menurut Semiawan (2010) metode penelitian kualitatif adalah jenis metode penelitian yang paling tepat dalam menangkap persepsi manusia hanya dengan kontak langsung dan fikiran terbuka serta lewat proses induktif dan interaksi simbolik manusia bisa mengenal dan mengerti sesuatu. Objek penelitiannya berupa UMKM, peneliti melakukan penelitian di Salatiga.

Teknik pengumpulan data yaitu observasi partisipasi, menurut (Tedlock, 1991) observasi partisipasi berarti peneliti melakukan pengamatan namun tidak berpartisipasi aktif dalam lokasi penelitian dan konteks di mana subyek peneliti hidup atau bekerja di dalamnya. Sumber data dari penelitian ini berasal dari data sekunder yang mana didapatkan dari sumber yang dianggap relevan dengan penelitian ini seperti, jurnal, paper, buku, artikel, website, dan sebagainya. Setelah data terkumpul akan didapatkan sebuah teori kesimpulan, selanjutnya penulis 
merumuskan penyelesaian dari permasalahan yang ada sehingga dapat memberikan hasil temuan dan dapat dijalankan oleh UMKM.

\section{HASIL PENELITIAN DAN PEMBAHASAN}

Salatiga adalah kota kecil di propinsi Jawa Tengah mempunyai luas wilayah $\pm 54,98 \mathrm{~km}^{2}$, terdiri dari 4 kecamatan, 23 kelurahan, berpenduduk 196.082 jiwa (Statistik Sektoral Kota Salatiga tahun 2020) (Salatiga, 2020).

Pandemi Covid-19 yang bermula pada tahun 2020 secara nyata telah mempengaruhi aktivitas perekonomian di seluruh Indonesia, termasuk Kota Salatiga. Menurut Badan Pusat Statistik Kota Salatiga, perekonomian di Salatiga didominasi oleh lapangan usaha Industri Pengolahan yaitu IKM (Industri Kecil Menengah) atau UMKM (Usaha Mikro Kecil Menengah) dengan kontribusi sebesar 32,23 persen. Kontribusi pada tahun ini lebih tinggi dibandingkan tahun sebelumnya dengan kontribusi tahun 2019 sebesar 31,26 persen. UMKM menjadi penyumbang terbesar dalam pertumbuhan perekonomian di Salatiga. Dengan adanya pengembangan UMKM, jumlah UMKM di Salatiga terus mengalami kenaikan disetiap tahunnya. Hingga tahun 2019 terdapat 1.969 jumlah UMKM yang ada di Salatiga (BPS, 2021).

Selama pandemi Covid-19 berlangsung memberikan dampak yang cukup signifikan terhadap pelaku usaha UMKM dikarenakan adanya kebijakan dari pemerintah berupa social distancing, physical distancing, PSBB (Pembatasan Sosial Berskala Besar), hingga PPKM (Pemberlakuan Pembatasan Kegiatan Masyarakat). Dengan adanya kebijakankebijakan dari pemerintah masyarakat hanya bisa stay at home. Maka dari itu, diperlukan adanya strategi bisnis yang tepat untuk meningkatkan jumlah pendapatan yang telah menurun akibat pandemi Covid-19 ini. Mengingat bahwa kondisi Covid-19 ini banyak sekali pembatasan-pembatasan yang berakibat pada perubahan pola perilaku konsumen. Strategi ini diharapkan dapat meningkatkan daya saing UMKM dan dapat mempertahankan keberlangsungan UMKM agar tetap eksis di tengah pandemi. Berikut strategi yang bisa diterapkan oleh UMKM supaya bisa tetap bertahan di tengah pandemi, diantaranya :

\section{E-Commerce}

Pada masa pandemi Covid-19 ini, mengakibatkan penurunan pendapatan bagi pelaku usaha UMKM. Hal ini terjadi karena adanya kebijakan dari pemerintah untuk mencegah penyebaran virus Covid19. Kebijakan ini berupa pembatasan jam operasional atau Pemberlakuan Pembatasan Kegiatan Masyarakat (PPKM). Dengan adanya pembatasan dari pemerintah mengakibatkan pola perilaku konsumen berubah, yang dulunya bisa kemana saja dengan bebas, setelah adanya pandemi ini masyarakat hanya bisa berdiam diri di rumah (stay at home). Yang dulunya membeli kebutuhan seharihari bisa datang ke toko langsung (offline), sekarang beralih ke online shopping yaitu, membeli apapun dari rumah. Maka dari itu, para pelaku UMKM harus melakukan strategi baru untuk menjangkau konsumen yaitu dengan memanfaatkan penjualan E-Commerce. Dengan memanfaatkan E-Commerce pelaku usaha dapat memperluas pangsa pasar, menjangkau lebih banyak konsumen, dan bisa dilakukan di mana saja.

Usaha Elektronik Commerce (ECommerce) atau lebih dikenal sebutan 
Online Shopping adalah pelaksanaan perniagaan berupa transaksi penjualan, pembelian, pemesanan, pembayaran, maupun promosi suatu produk barang dan/atau jasa dilakukan dengan memanfaatkan komputer dan sarana komunikasi elektronik digital atau telekomunikasi data. Selain itu, bentuk perniagaan ini juga dapat dilakukan secara global, yaitu dengan menggunakan jaringan internet (Kuswiratmo, 2016). Dengan memanfaatkan E-commerce sebagai media pemasaran pelaku usaha UMKM di masa pandemi Covid-19 ini merupakan strategi yang cocok untuk diterapkan. Selain mencegah penularan Covid-19, konsumen bisa bebas memilih apa yang akan di beli dan dapat melihat harganya secara langsung. Misalnya saja dalam $E$-Commerce makanan, bagi pelaku usaha dengan menggunakan E-Commerce akan lebih efisien, baik tempat maupun produk. Dikarenakan produksi bisa dilakukan di rumah dan pelaku usaha akan membuat produk jika ada pesanan, jadi tidak ada produk yang sia-sia atau terbuang percuma. Para pelaku usaha UMKM dapat memanfaatkan beberapa $E$ Commerce yang ada di Indonesia yaitu, Shopee, GoJek, Lazada, Blibli.com, Lazada, Tokopedia, Buka Lapak, dan sebagainya.

Berdasarkan penelitian HELMALIA \& AFRINAWATI, (2018) tentang "Pengaruh E-Commerce Terhadap Peningkatan Pendapatan Usaha Mikro Kecil dan Menengah di Kota Padang" mengatakan bahwa E-Commerce berpengaruh positif dan signifikan terhadap pendapatan UMKM. Akan tetapi hal ini berlawanan dengan penelitian yang telah dilakukan oleh (Hardilawati, 2019) yaitu tentang "Model Pemasaran Hubungan Pelanggan, Inovasi dan $E$ Commerce Dalam Meningkatkan Kinerja Pemasaran UKM di Pekanbaru” mengatakan bahwa terkait dengan usaha kecil, E-Commerce memiliki pengaruh yang positif, tetapi tidak signifikan terhadap peningkatan kinerja pemasaran. Hal ini dikarenakan minimnya pengetahuan pelaku usaha UMKM terkait dengan penggunaan E-Commerce. Perlu adanya bantuan dari pihak ketiga yaitu pemerintah atau praktisi yang mengetahui E-Commerce, supaya pelaku usaha menjadi lebih melek akan E-Commerce dan cara pemanfaatannya.

Seiring dengan perkembangan industri 4.0 yang aktivitasnya serba digital, seharusnya pelaku usaha sudah mempersiapkan diri untuk lebih melek lagi dengan penggunaan teknologi digital. Dengan adanya pandemi Covid-19 ini pemanfaatan perdagangan secara $E$ Commerce menjadi pilihan yang tepat bagi para pelaku usaha agar tetap bisa bertahan di tengah pandemi.

Keunggulan penggunaan ECommerce bagi pelaku usaha menurut, Akyaz, 2018; Buyukseymen, 2018; am, 2014; Germir, 2015; Gokmen, 2019; Zturk, 2019 dalam (Guven, 2020) mengatakan bahwa (1) Penjual lebih mudah mengakses ke pelanggan. (2) Pelanggan dapat melaporkan masalah mereka selama berbelanja melalui situs E-Commerce. (3) File database penting tentang pelanggan yang ada dan potensial dapat diperoleh dan layanan yang diperonalisasikan dapat ditawarkan kepada pelanggan dengan data. (4) Periklanan dapat dilakukan melalui situs E-Commerce. (5) Persiapan atau penyediaan pesanan setelah permintaan pelanggan, memungkinkan perusahaan bekerja dengan stok minimum. (6) toko online dapat memantau kompetitornya yang melakukan aktivitas penjualan. (7) Pelanggan dapat dihubungi langsung menggunakan artificial intelligent. (8) 
Dapat mempromosikan produk dan jasanya dengan lebih mudah baik nasional maupun internasional tanpa batasan ruang dan waktu. (9) Toko online bisa buka 24 jam sehari, 356 hari setahun. (10) memberikan kesempatan kepada bisnis kecil untuk tumbuh dan bersaing dengan tujuan mereka. (11) karena banyak transaksi dilakukan secara otomatis melalui komputer, kebutuhan pribadi dapat dikurangi, sehingga menghemat biaya.

Dengan menggunakan ECommerce para pelaku usaha UMKM dapat meningkatkan pangsa pasar, meluaskan jangkauan konsumen baik nasional maupun internasional, stok minimum, buka setiap hari, serta akan lebih efektif dan efisien dalam menjalankan usaha.

\section{Digital Marketing}

$\begin{array}{ccc}\text { Selama } & \text { pandemi } & \text { Covid-19 } \\ \text { berlangsung } & \text { terjadi } & \text { penurunan } \\ \text { perekonomian dan para pelaku UMKM }\end{array}$
juga ikut terkena dampaknya. Penurunan ekonomi ini diakibatkan karena menurunnya jumlah konsumen, sehingga penjualan menjadi menurun. Dengan menurunnya jumlah konsumen, pasti menjadi problematika besar bagi pelaku usaha UMKM. Hal yang harus dilakukan oleh pelaku usaha UMKM yaitu mencari tahu bagaimana caranya agar konsumen bisa bertambah lagi dan bagaimana cara memasarkan produknya. Untuk memasarkan produk yang maksimal para pelaku usaha UMKM harus berpikir kreatif dan inovatif untuk melakukan perubahan strategi pemasarannya. Mengingat teknologi sekarang sudah berkembang pesat, sehingga mengharuskan para pelaku UMKM untuk bisa bersaing secara global melalui digital marketing. Dengan kebiasaan masyarakat yang setiap harinya tidak bisa lepas dari internet, maka pelaku usaha UMKM harus bisa memanfaatkan digital marketing sebagai pemasaran produknya, agar tetap bertahan di tengah pandemi Covid-19 ini.

Digital marketing merupakan pencapaian tujuan pemasaran melalui penerapan media digital, data, dan teknologi (Chaffey \& Chadwick, 2019). Seiring dengan perkembangan teknologi, digital marketing dapat dimanfaatkan oleh para pelaku usaha UMKM dalam melakukan strategi pemasarannya. Maka dari itu, menjadi sebuah keharusan para pelaku usaha UMKM untuk mempelajari dan memahami digital marketing. Media digital marketing yang dapat digunakan oleh pelaku usaha dalam memasarkan produknya yaitu bisa melalui Facebook, Instagram, Twitter, Tiktok, Youtube, dan sebagainya. Dengan banyaknya jumlah pengguna media sosial saat ini, menjadi peluang yang besar bagi pelaku usaha UMKM dalam memperluas jangkauan pemasarannya.

Berdasarkan penelitian yang telah dilakukan oleh (Hendrawan et al., 2019) menyatakan bahwa digital marketing mempengaruhi kinerja penjualan produk UMKM. Dari 70\% pengusaha kreatif menyatakan bahwa digital marketing akan menjadi sarana utama dalam hal pemasaran, sedangkan offline store menjadi sarana pelengkapnya. Karena mengingat kemudahan-kemudahan yang dapat ditemukan dalam digital marketing menjadikannya tempat terbaik dalam berbelanja (online shopping). Maka dari itu, para pelaku usaha harus memberanikan diri untuk mencoba hal baru dengan menggunakan digital marketing sebagai media pemasarannya. Dimulai dengan membuat akun dan aktif melakukan promosi di media sosial. Perlu adanya kepercayan diri yang tinggi, karena 
sangatlah sulit untuk mendapatkan kepercayaan dari konsumen.

Adapun model marketing yang mapan menurut (Kingsnorth, 2019) dalam bukunya yaitu terdapat 4 poin dari marketing (The 4 Ps of Marketing), yaitu produk (product), harga (price), tempat (place), dan promosi (promotion). (1) Produk, produk dapat dipasarkan melalui online, baik media digital marketing ataupun E-Commerce. Pelaku usaha UMKM harus berinovasi dan berpikir kreatif dalam mengemas produk semenarik mungkin, supaya para konsumen tertarik ingin membeli produk yang dijual. (2) Harga, harga menjadi pengaruh utama dalam keputusan pembelian produk. Para pelaku UMKM dapat menarik konsumen dengan pemberlakuan cashback dan voucher. Hal ini dikarenakan, adanya konsep perbandingan harga yang cepat dalam digital marketing, diharapkan dengan pemberlakuan cashback dan voucher dapat menarik minat konsumen untuk membeli. (3) Tempat, toko dalam digital marketing bukan merupakan toko yang berbentuk fisik, melainkan toko online. Permasalahannya adalah bagaimana caranya agar toko online mudah untuk ditemukan dalam mesin pencarian. Caranya adalah dengan meningkatkan trafik toko, yaitu dengan memasang iklan, melakukan optimasi (SEO), dan memanfaatkan media sosial untuk memasarkan produk. (4) Promosi, para pelaku usaha UMKM harus melakukan promosi secara berulang-ulang. Promosi bisa dilakukan dengan pembuatan video, pamflet, dan sebagainya, atau bisa melakukan live promosi produk menggunakan media sosial. Jika strategi ini dilakukan secara benar dan terusmenerus, akan memberi dampak baik bagi pelaku usaha UMKM terhadap bisnisnya.
Ketika melakukan pemasaran dengan digital marketing, para pelaku usaha UMKM juga harus mengetahui dan mengenali sasaran konsumennya. Dengan begitu, strategi pemasaran yang dilakukan akan tepat sasaran dan tepat tujuan.

\section{Perbaikan Kualitas Produk dan Pelayanan}

Dengan adanya pandemi Covid-19 memberikan dampak yang cukup besar pada sektor UMKM. Selama pandemi Covid-19 berlangsung mengakibatkan pola perilaku konsumen berubah, kini konsumen lebih berhati-hati dalam melakukan transaksi jual beli. Selain itu, kepercayaan konsumen terhadap barang dan jasa yang diperjualbelikan juga menurun serta adanya pembatasan terhadap aktivitas konsumen, hal ini berimbas pada penurunan omset pelaku usaha UMKM. Maka dari itu, para pelaku usaha UMKM harus melakukan strategi baru, berupa upaya untuk mendapatkan kepercayaan konsumen kembali. Strategi ini bisa dilakukan dengan memperbaiki kualitas produk dan memperbaiki kualitas pelayanannya, tujuannya untuk menigkatkan tingkat kepercayaan konsumen kembali terhadap produk dan atau jasa yang dipasarkan oleh pelaku usaha UMKM.

Berdasarkan penelitian yang dilakukan oleh Jackson R.S. Weenas, (2013) menyatakan bahwa kualitas produk dan pelayanan konsumen berpengaruh positif terhadap keputusan pembelian. Hal ini dapat menimbulkan kepuasan dan sikap loyal dari konsumen terhadap pelaku usaha UMKM. Maka dari itu, para pelaku usaha UMKM harus memiliki inovasi baru dan berpikir kreatif supaya dapat meningkatkan kepercayaan konsumen melalui perbaikan kualitas produk dan pelayanannya. 
Kualitas produk merupakan hal penting yang perlu diperhatikan oleh konsumen. Konsumen akan mempertimbangkan pengorbanan sejumlah uang yang dimilikinya dengan barang dan atau jasa yang akan dibeli. Menurut Kotler \& Amstrong (2010) kualitas produk adalah kemampuan suatu produk untuk melaksanakan fungsinya, meliputi kehandalan, daya tahan, ketepatan, kemudahan operasi, dan perbaikan produk, serta atribut bernilai lainnya. Kualitas produk akan tercapai apabila produk tersebut mudah digunakan, memiliki daya tahan yang baik, bisa diketahui kejelasan fungsinya, dan sebagainya.

Untuk meningkatkan kualitas produk, para pelaku usaha UMKM dapat menekankan pada kebersihan dan keamanan produk. Mengingat, selama pandemi ini aktivitas jual beli dilakukan secara online. Jadi, produk yang akan dikirimkan kepada konsumen harus memiliki ketahanan yang baik, baik berupa produk ataupun cara pengemasannya.

Selain kualitas produk, kualitas pelayanan juga berpengaruh terhadap tingkat kepuasan konsumen. Menurut Tjiptono (2009) kualitas pelayanan adalah tingkat keunggulan yang diharapkan dan pengendalian atas tingkat keunggulan tersebut untuk memenuhi keinginan pelanggan. Dengan menggunakan $E$ Commerce atau digital marketing dalam melakukan transaksi jual beli, konsumen akan puas ketika pelayanannya cepat (gercep) dan ramah. Ketika pelayanan dari pelaku usaha baik, maka akan terjalin komunikasi yang baik pula terhadap konsumen. Sehingga konsumen akan merasa nyaman dan akan berlangganan dengan toko online tersebut. Selain itu kualitas pelayanan jasa pengirim barang juga menjadi penentu tingkat kepuasan pelanggan. Pelanggan akan puas jika produk yang dipesannya sesuai dengan apa yang dipesan, barang selamat sampai tujuan, dan pengemasannya baik. Maka dari itu, para pelaku usaha UMKM bisa meningkatkan kualitas pengemasan produk, berupa keamanan,kebersihan, dan ketahanan produk. Supaya dalam pengiriman produk tidak terjadi kerusakan pada barang yang berakibat pada kekecewaan konsumen.

Ketika kualitas produk dan kualitas pelayanan baik, konsumen akan merasa nyaman dan yakin dalam berbelanja. Hal tersebut akan menimbulkan rasa kepercayaan konsumen, kemudian konsumen akan meras puas dan akan menunjukkan sikap loyal terhadap toko online tersebut. Kepuasan konsumen menjadi kunci utama ketika melakukan transaksi jual beli secara online menggunakan media E-Commerce atau market place.

\section{Customer Relationship Marketing (CRM)}

Selama pandemi Covid-19 ini berlangsung, para pelaku usaha UMKM berinovasi dan berfikir kreatif untuk meningkatkan pendapatan dan memperluas jangkauan pemasaran konsumen. Sebaiknya, para pelaku usaha UMKM tidak hanya memperluas jangkauan konsumen untuk mendapatkan pelanggan baru, tetapi juga tetap mempertahankan kualitas produk dan pelanggan yang sudah ada. Pelanggan akan mencapai kepuasannya jika kualitas produk dan kualitas pelayanannya baik. Ketika pelanggan sudah percaya dengan produk yang dipasarkan, maka pelanggan akan loyal dan tidak akan berpindah ke produk lain. Salah satu langkah yang dapat diambil oleh para pelaku usaha UMKM dalam mempertahankan loyalitas 
pelanggan yaitu dengan melakukan pemasaran hubungan pelanggan (Customer Relationship Marketing).

Menurut Kotler \& Amstrong (2010) relationship marketing merupakan orientasi bisnis yang terfokus pada menjaga hubungan baik dengan pelanggan yang sudah ada dan membangun hubungan yang erat dan saling menguntungkan antara pelaku usaha dan konsumen hingga menciptakan transaksi ulang hingga terbentuk loyalitas konsumen. Customer relationship marketing adalah sebuah strategi pemasaran untuk menjalin hubungan jangka panjang dengan para pelanggannya. Hal ini dilakukan untuk menciptakan loyalitas konsumen dan transaksi ulang pelanggan untuk membeli produk kembali.

Strategi customer relationship marketing cocok untuk dilakukan oleh para pelaku usaha UMKM pada saat pandemi Covid-19, hal ini dikarenakan dapat memberikan pengaruh yang positif dalam meningkatkan kepuasan dan loyalitas pelanggan. Seperti penelitian yang dilakukan oleh Akbar, (2018) menyatakan bahwa relationship marketing berpengaruh positif terhadap kepuasan pelanggan dan loyalitas pelanggan. Semakin baik hubungan pelaku usaha UMKM dengan konsumen, pemasok, dan pelaku lainnya , maka akan semakin baik pula kemampuan peningkatan kinerja pemasaran. Namun, berbeda dengan penelitian yang dilakukan oleh (Hardilawati, 2019) yang menyatakan bahwa customer relationship marketing memiliki pengaruh yang positif namun tidak signifikan terhadap peningkatan kinerja UMKM. Hal ini bisa terjadi, karena keterbatasan pelaku UMKM dan kurang maksimalnya dalam menjalankan strategi customer relationship marketing.
Pada masa pandemi Covid-19 ini, para pelaku usaha UMKM ketika ingin menjalin hubungan dengan pelanggan, bisa dilakukan dengan menunjukkan sikap empatinya terhadap konsumen yang ikut terdampak pandemi Covid-19. Bentuk empatinya, bisa berupa pemberian diskon atau promo ketika pelanggan membeli produk. Dengan hal itu, akan menjalin hubungan yang baik dan tingkat kepercayaan konsumen akan tinggi terhadap pelaku usaha. Jadi, pada masa pandemi ini, pelaku usaha UMKM tidak hanya memikirkan dirinya sendiri,tetapi juga memikirkan orang lain yang terdampak pandemi Covid-19 ini. Selain itu, para pelaku usaha UMKM dapat menjalin komunikasi dengan pelanggan melalui media online. Pelaku usaha merespon dengan baik apapun yang ditanyakan oleh pelanggan, apapun keluh kesah yang diungkapkan, diharapkan dapat memberikan solusi terbaiknya.

\section{KESIMPULAN}

Pandemi Covid-19 telah mempengaruhi aktivitas ekonomi Indonesia, banyak sektor yang terdampak oleh pandemi Covid-19 ini, salah satunya sektor UMKM. UMKM merupakan salah satu sektor yang mendominasi pekerjaan yang ada di Indonesia. Akibat adanya pandemi Covid-19 terdapat beberapa pengaruh besar yang dirasakan pada sektor UMKM, diantaranya penurunan konsumsi dan daya beli masyarakat, penurunan kinerja perusahaan, ancaman pada sektor perbankan dan keuangan, serta penurunan eksistensi UMKM yang akhirnya berdampak pada pemutusan hubungan kerja (PHK) dan ancaman macetnya pembayaran kredit. Dengan beberapa ancaman yang menghantui para pelaku usaha UMKM diprediksi pendapatan konsumen akan menurun 
secara signifikan. Untuk itu perlu adannya strategi baru supaya para pelaku usaha UMKM dapat bertahan di masa pandemi ini.

Berikut strategi baru yang dapat diterapkan UMKM supaya bisa bertahan di tengah pandemi, yaitu: (1) Melakukan penjualan E-Commerce. (2) Melakukan pemasaran dengan digital marketing. (3) Memperbaiki kualitas produk dan layanan, serta (4) Menjalin hubungan baik dengan konsumen (Customer Relationship Marketing). Dengan berberapa strategi baru, pelaku usaha UMKM akan bertahan di masa pandemi, bukan hanya itu saja jangkauan pasar akan menjadi lebih luas lagi.

\section{SARAN}

Dengan adanya rumusan strategi baru di atas pelaku usaha UMKM diharapkan dapat mengembangkan dirinya mengikuti perkembangan zaman pada era teknologi digital pada saat ini. Pemerintah sebagai pihak ketiga diharapkan dapat memberikan pelatihan dan pendidikan mengenai teknologi digital. Serta, begi peneliti selanjutnya diharapkan dapat mengembangkan dan melihat tingkat keberhasilan atas rumusan strategi di atas, yang nantinya sebagai bahan evaluasi.

\section{DAFTAR PUSTAKA}

Akbar, I. (2018). PENGARUH RELATIONSHIP MARKETING DAN RELATIONSHIP QUALITY TERHADAP LOYALITAS PELANGGAN DENGAN KEPUASAN PELANGGAN SEBAGAI VARIABEL INTERVENING. Indonesia Jurnal of Strategic Manajemen, 1(1), 82-97. https://doi.org/https://doi.org/10.25 134/ijsm.v1i1.844

Alfin, A. (2021). ANALISIS STRATEGI
UMKM DALAM MENGHADAPI KRISIS DI ERA PANDEMI COVID19. Jurnal Inovasi Penelitian, 1(8), 1543-1552.

Dhyah Ayu Retno Widyastuti, R. N., \& Sidhi, dan T. A. P. (2016). LITERASI DIGITAL PADA PEREMPUAN PELAKU USAHA PRODUKTIF DI DAERAH ISTIMEWA YOGYAKARTA Dhyah. Jurnal ASPIKOM, 3(1), 1-15. http://jurnalaspikom.org/index.php/ aspikom/article/view/95

Guven, H. (2020). Industry 4.0 and Marketing 4.0: In Perspective of Digitalization and E-Commerce. Agile Business Leadership Methods for Industry 4.O, 25-46. https://doi.org/10.1108/978-1-

80043-380-920201003

HELMALIA, H., \& AFRINAWATI, A. (2018). Pengaruh E-Commerce Terhadap Peningkatan Pendapatan Usaha Mikro Kecil Dan Menengah Di Kota Padang. JEBI (Jurnal Ekonomi Dan Bisnis Islam), 3(2), 237. https://doi.org/10.15548/jebi.v3i2.18 2

Hendrawan, A., Sucahyowati, H., Cahyandi, K., Indriyani, \& Rayendra, A. (2019). PENGARUH MARKETING DIGITAL TERHADAP KINERJA PENJUALAN PRODUK UMKM ASTI GAURI DI KECAMATAN BANTARSARI CILACAP. Jurnal Administrasi Dan Kesekretarisan, 4(1), 50-61. http://jurnal.stikstarakanita.ac.id/index.php/JAK/artic le/view/189

Hidayat, W. W., Soehardi, S., Prasetyo, E. T., \& Husadha, C. (2021). Implications of Covid-19 Pandemic on MSMEs to Economy, Society: Case in the Country of Indonesia. Systematic Reviews in Pharmacy, 12(4), 71-78. https://doi.org/https://www.sysrevp harm.org/articles/implications-ofcovid19-pandemic-on-msmes-to- 
economy-society-case-in-thecountry-of-indonesia.pdf

Jackson R.S. Weenas. (2013). KUALITAS PRODUK, HARGA, PROMOSI DAN KUALITAS PELAYANAN PENGARUHNYA TERHADAP KEPUTUSAN PEMBELIAN SPRING BED COMFORTA. Jurnal EMBA, 1(4), 607-618.

Yamali, F. R., \& Putri, R. N. (2020). Dampak Covid-19 Terhadap Ekonomi Indonesia. 4(September), 384-388.

https://doi.org/10.33087/ekonomis. v4i2.179

BPS. (2021, Maret 01). Pertumbuhan Ekonomi Kota Salatiga Tahun 2020. Dipetik Mei 2021, 25, dari salatigakota.bps.go.id: https://salatigakota.bps.go.id

Catriana, E. (2021, Januari 1). Riset Bank DBS Indonesia: Selama Pandemi Pelanggan E-Commerce Nail Menjadi 66 Persen. Dipetik Mei 28, 2021, dari kompas.com: https://www.google.com/amp/s/a mp.kompas.com

Chaffey, D., \& Chadwick, F. E. (2019). Digital Marketing. New York: Pearson.

Covid19.go.id. (t.thn.). Dipetik Mei 28, 2021, dari Covid19.go.id: https://covid19.go.id

Goel, R. (2007). E-Commerce. New Age International.

Hanoatubun, S. (2020). Dampak Covid-19 Terhadap Perekonomian Indonesia. Journal of Education, Psychology and Counseling vol 2, no 1, 146-153.

kemenkopukm.go.id. (t.thn.). Dipetik Mei 28, 2021, dari kemenkopukm.go.id: https://www.kemenkopukm.go.id
Kingsnorth, S. (2019). Digital Marketing Strategy An Integrated Approach to Online Marketing. New York: KoganPage.

Kotler, P., \& Amstrong, G. (2010). Priciples of Marketing. Boston: Pearson.

Kuswiratmo, B. A. (2016). Memulai Usaha Itu Gampang. Jakarta: Visimedia.

Maulina, E., \& Sari, M. N. (2017). Kebijakan dan Strategi Bisnis Wanita Pengusaha: Studi pada Usaha Kecantikan Salon NADISSE. AdBispreneur vol 2, no 1, 69-78.

Nasir, M. S., \& Khoirudin, R. (2020). Pengendalian Manajemen Usaha yang Ideal pada UMKM Haha Multi Creative. Seminar Nasional Hasil Pengabdian Kepada Masyarakat, 245-250.

Pemkot Salatiga. (2020). Pemerintah Kota Salatiga-Hati Beriman. Dipetik Mei 2021, 25, dari salatiga.go.id: https://salatiga.go.id

Semiawan, C. R. (2010). Metode Penelitian Kualitatif Jenis, Karakteristik, dan Keunggulannya. Jakarta: Grasindo.

Soehardi, S., \& Sable, S. C. (2019). Strategi Pemasaran Bisnis Pariwisata Di Kota Davao, Filipina. Jurnal Ilmiah Manajemen Ubhara, 1(2), 1-13. https://doi.org/10.31599/jmu.v1i2. 674

Tedlock. (1991). From Participant Observation to The Observation of Participation: The Emergence of Narrative Ethnography. Journal of Anthropological Research, 69-94.

Tjiptono. (2009). Service Marketing: Esensi dan Aplikasi. Yogyakarta: Marknesis. 